\title{
Renal transplant complications: Moving toward comparison of relevant parameters and further improvement in outcomes
}

Ronald B. Moore, MD, PhD, FRCSC, FACS

Department of Surgery and Oncology, University of Alberta, Edmonton, AB, Canada

Cite as: Can Urol Assoc J 2017; Epub ahead of print. http://dx.doi.org/10.5489/cuaj.4990

Published online November 1, 2017

***

The article, "Complications in the 90-day postoperative period following kidney transplant and the relationship of the Charlson Comorbidity Index," from our institution, is unique in highlighting Clavien graded complications of renal transplant (RenTx) at a single institution over a 90-day postoperative window. The paper has its limitations, including its retrospective nature, abstracted data, and non-procedure-specific reported complications, which the authors acknowledge. It highlights the relative degree of complications between cystectomy and liver transplantations in the discussion, but doesn't address or discuss the existing risks of these complications in the dialysis (D) and non-dialysis (ND) chronic kidney disease (CKD) population.

There is a high incidence of cardiovascular (CV) disease in the CKD population (10-40 times), with a report of CV event at transplant as high as $10 \% .{ }^{1,2}$ In addition, there is a high incidence of anemia in the CKD population despite the use of synthetic erythropoietin (EP). Large studies have shown an increased incidence of CV complications in CKD patients treated aggressively with EP. Most CKD programs, therefore, only treat with EP to a target hemoglobin of 90-110 G/L (similar to the level seen in this study). Even with this target level, 10-20\% of NDCKD patients are transfused when admitted to hospital for other causes (likely on the basis of blood work and myelosuppression). ${ }^{3}$ This incidence is likely higher in the hemodialysis population, where there is potential for injury to red blood cells (RBCs) and the risk of filter clotting, the risk of which is higher in patient that can not receive anticoagulation with their dialysis run (as in the case of perioperative RenTx or other surgeries). A prior study looking at the effects of blood transfusion after RenTx reported a $45 \%$ transfusion rate, with $36 \%$ occurring within the first month of transplantation. ${ }^{4}$

I think it is also important to state that in our socialized healthcare system, RenTx is performed for three key benefits: quality of life, survival, and cost-saving. Multiple studies have shown that the sooner a person can be transplanted (ideally pre-emptively), the better the outcomes; however, the demand outstrips the supply despite many strategies to increase the number of donor kidneys. This has lead to many kinds of deceased donor kidneys (expanded criteria donor [ECD], determination by cardiac death [DCD] as opposed to neurological determination of death [NDD], and exceptional release kidneys [usually infective risk]), all with 


\section{Renal transplant complications}

different risks. Regardless, all patients benefit from a RenTx if they get a functioning allograft and the perioperative risks are not too high. ${ }^{5}$ The risk-benefit ratio, however, takes different times to be realized, depending on the health of the recipient (up to 325 days); in fact, some of the higher-risk patients see the greatest benefit, as was originally pointed out by Federick Port et al, among others. ${ }^{6-8}$ With a functioning RenTx, the estimated cost saving to the Canadian healthcare system is $\$ 250000 /$ five years. ${ }^{9}$

Today, we are transplanting more elderly patients, and a greater percentage has end-stage renal disease (ESRD) secondary to diabetic nephropathy. Despite this, it is reassuring to see that the outcomes are unchanged or improved, with similar one-year survival rates. ${ }^{10}$ In the not-toodistant future, the American College of Surgeons will launch its Transplant Quality Improvement Program (TransQIP). ${ }^{11}$ At present, this program is in the beta phase of testing, but when implemented across all programs, it will hopefully allow comparison of relevant parameters and further improvement in transplant outcomes. 


\section{References}

1. Hart A, Weir MR, Kasiske BL. Cardiovascular risk assessment in kidney transplantation. Kidney Int 2015;87:527-34. https://doi.org/10.1038/ki.2014.335

2. Shroff GR, Akkina SK, Miedema MD, et al. Troponin I levels and postoperative myocardial infarction following renal transplantation. Am J Nephrol 2012;35:175-80. https://doi.org/10.1159/000335679

3. Lawler EV, Bradbury BD, Fonda JR, et al. Transfusion burden among patients with chronic kidney disease and anemia. Clin J Am Soc Nephrol 2010;5:667-72. https://doi.org/10.2215/CJN.06020809

4. Scornik JC, Schold JD, Bucci M, et al. Effects of blood transfusions given after renal transplantation. Transplantation 2009;87:1381-6. https://doi.org/10.1097/TP.0b013e3181a24b96

5. Tonelli M, Wiebe N, Knoll G, et al. Systematic review: Kidney transplantation compared with dialysis in clinically relevant outcomes. Am J.Transplant 2011;11:2093-109. https://doi.org/10.1111/j.1600-6143.2011.03686.x

6. Port FK, Wolfe RA, Mauger EA, et al. Comparison of survival probabilities for dialysis patients vs cadaveric renal transplant recipients. JAMA 1993;270:1339-43. https://doi.org/10.1001/jama.1993.03510110079036

7. Wolfe RA, Ashby VB, Milford EL, et al. Comparison of mortality in all patients on dialysis, patients on dialysis awaiting transplantation, and recipients of a first cadaveric transplant. N Engl J Med 1999;341:1725-30. https://doi.org/10.1056/NEJM199912023412303

8. Gill JS, Lan J, Dong J, et al. The survival benefit of kidney transplantation in obese patients. Am J Transplant 2013;13:2083-90. https://doi.org/10.1111/ajt.12331

9. Kidney Foundation of Canada. Available at https://www.kidney.ca/. accessed October 23, 2017.

10. Canadian Institute for Health Information 2016. Available at https://www.cihi.ca/en. Accessed October 23, 2017

11. Parekh J, Ko C, Lappin J, et al. Transplant-specific quality initiative - introducing TransQIP: A joint effort of the ASTS and ACS. Am J Transplant 2017;17:1719-22. https://doi.org/10.1111/ajt.14315 